\title{
Serological evaluation of Neospora caninum in pregnant women treated at referral center for prenatal screening in Mato Grosso do Sul, Brazil
}

\author{
Avaliação sorológica de Neospora caninum em gestantes atendidas em centro \\ de referência para triagem pré-natal em Mato Grosso do Sul, Brasil
}

Pâmella Oliveira Duarte1; Bárbara Guimarães Csordas²; Leandra Marla Oshiro²; Leandro de Oliveira Souza Higa'; Namor Pinheiro Zimmermann²; Kauê Rodriguez Martins33; Jacqueline Cavalcante Barros; Renato Andreottij ${ }^{4 *}$ (1)

\author{
'Programa de Pós-graduação em Doenças Infecciosas e Parasitárias, Universidade Federal de Mato Grosso do Sul - UFMS, Campo \\ Grande, MS, Brasil \\ ${ }^{2}$ Laboratório de Biologia Molecular do Carrapato, Departamento de Sanidade Animal, Empresa Brasileira de Pesquisa Agropecuária - \\ Embrapa Gado de Corte, Campo Grande, MS, Brasil \\ ${ }^{3}$ Programa de Pós-graduação em Ciências Veterinárias, Universidade Federal de Mato Grosso do Sul - UFMS, Campo Grande, MS, Brasil \\ ${ }^{4}$ Departamento de Sanidade Animal, Empresa Brasileira de Pesquisa Agropecuária - Embrapa Gado de Corte, Campo Grande, MS, Brasi
}

How to cite: Duarte PO, Csordas BG, Oshiro LM, Higa LOS, Zimmermann NP, Martins KR, et al. Serological evaluation of Neospora caninum in pregnant women treated at referral center for prenatal screening in Mato Grosso do Sul, Brazil. Braz J Vet Parasitol 2020; 29(4): e010820. https://doi.org/10.1590/S1984-29612020097

\begin{abstract}
Neospora caninum is an obligate intracellular protozoan with canids (Canis domesticus, Canis lupus dingo, Canis latrans, Canis lupus) as its definitive hosts. The objective of this study was to detect anti-N. caninum antibodies in pregnant women seen at referral center for prenatal screening in the state of state Mato Grosso do Sul, Brazil. A total of 188 serum samples from pregnant women provided by the Instituto de Pesquisa, Ensino e Diagnósticos da APAE de Campo Grande (IPED/ APAE) were subjected to IFA test and western blot analysis. The samples were divided into three groups: 23/99 samples from the seropositive group for toxoplasmosis were positive for anti-N. caninum IgG antibodies, and 9/99 positive for IgM; in the HIV group, 7/33 were positive for IgG; and in the HIV+toxoplasmosis group, 13/56 were positive for IgG and two positive for IgM. The seropositivity for IgG was assessed by western blot by testing 43 IFA test positive samples using rNcSRS2 (Nc-p43) as antigen. The serological results of the present study suggest that exposure of these pregnant women to the parasite $N$. caninum and presence of IgM antibodies are indicative of recent infection. Further studies are needed to establish the possibility of active infection.
\end{abstract}

Keywords: Pregnant women, Neospora caninum, IFA test, Western blot.

\begin{abstract}
Resumo
Neospora caninum é um protozoário intracelular obrigatório que possui os canídeos (Canis domesticus, Canis lupus dingo, Canis latrans, Canis lupus) como seus hospedeiros definitivos. O objetivo deste trabalho foi detectar anticorpos anti-N. caninum em gestantes, atendidas em centro de referência para triagem pré-natal, em Mato Grosso do Sul, Brasil. Um total de 188 amostras de soro de gestantes, cedidas pelo Instituto de Pesquisa, Ensino e Diagnósticos da APAE de Campo Grande (IPED/ APAE), foram submetidas ao teste de RIFI e western blot para a detecção de anticorpos anti-N. caninum. As amostras foram divididas em três grupos: 23/99 amostras do grupo soropositivo para toxoplasmose demonstraram positividade para anticorpos IgG anti-N. caninum e 9/99 positivos para IgM. No grupo HIV 7/33 apresentaram positividade para IgG. No grupo HIV+Toxoplasmose 13/56 apresentaram positividade para IgG e duas para IgM. A soropositividade para IgG foi avaliada por western blot, testando 43 amostras positivas para RIFl, usando-se rNcSRS2 (Nc-p43) como antígeno. Os resultados sorológicos do presente estudo sugerem exposição dessas gestantes ao parasita N. caninum e a positividade para anticorpos IgM são indicativos de infecção recente. Mais estudos na área são necessários para estabelecer a possibilidade de infecção ativa.
\end{abstract}

Palavras-chave: Gestante, Neospora caninum, RIFI, Western blot. 


\section{Introduction}

Neospora caninum is an obligate intracellular protozoan that belongs to the phylum Apicomplexa (Dubey et al., 1988). It emerged as a serious disease in cattle and dogs (Dubey, 2003), with canids (Canis domesticus, Canis lupus dingo, Canis latrans, Canis lupus) as definitive hosts (McAllister et al., 1998; King et al., 2010; Gondim et al., 2004; Dubey et al., 2011). The forms of transmission are similar to toxoplasmosis and can be horizontal or vertical. The horizontal form occurs in herbivores via ingestion of water or food contaminated by oocysts and in carnivores via ingestion of tissues infected by tachyzoites or tissue cysts. Vertical transmission occurs transplacentally (Dubey et al., 2007).

Serological and molecular studies of $N$. caninum in humans and particularly in pregnant women are still scarce in the literature. As there is a report of detection of $N$. caninum DNA in two human umbilical cord blood samples (Duarte et al., 2020) and this parasite is so similar to T. gondii (Barratt et al., 2010; Hemphill et al., 1999) which is responsible for congenital toxoplasmosis, it is important to investigate the prevalence of $N$. caninum in pregnant women. For this reason, the objective of this study was to detect anti-N. caninum antibodies in pregnant women treated at a referral center for prenatal screening in the state of Mato Grosso do Sul, Brazil.

\section{Material and Methods}

\section{Sample acquisition and data collection}

The study was approved by the Ethics Committee on Research Involving Human Subjects of the Federal University of Mato Grosso do Sul (Universidade Federal de Mato Grosso do Sul - UFMS) on November 3, 2016, under document n. 1,804,047. A total of 188 serum samples from 46 municipalities of the state of Mato Grosso do Sul were provided by the Instituto de Pesquisa, Ensino e Diagnósticos da APAE de Campo Grande (IPED/ APAE), located in Campo Grande, Mato Grosso do Sul. These samples were divided into three groups: group I contained samples from 99 pregnant women serologically positive for toxoplasmosis in the active phase with IgG/IgM positivity; group II contained samples from 33 human immunodeficiency virus (HIV)-positive pregnant women; and group III contained samples from 56 pregnant women positive for HIV and IgG toxoplasmosis antibodies. Data were collected from the reports provided by IPED/ APAE, which included the results of the prenatal screening tests.

\section{IFA test}

Indirect fluorescent antibody (IFA) testing for the detection of anti-N. caninum antibodies was performed using the commercial diagnostic kit Imunoteste ${ }^{\circledR}$ Neospora (RIFI) (Imunodot Diagnostics, Jaboticabal, São Paulo, Brazil) following the manufacturer's recommendations, with modifications. The serum samples were initially diluted 1:50, and positive and negative human serum controls established previously during work conducted at the laboratory were used (Oshiro et al., 2015). Human anti-IgG and anti-IgM fluorescent conjugates (1:100 dilution; conjugated with fluorescein isothiocyanate - Sigma-Aldrich, St. Louis, Missouri, USA) were used for the serological tests. The protocol for IFA test was adapted from Paré et al. (1995).

\section{Western blot analysis}

For the western blot, a recombinant partial sequence of the NcSRS2 protein (Nc-p43) was used, which presents approximately $29 \mathrm{KDa}$ and the protocol was adapted from Lima et al. (2007).

\section{Statistical analysis}

The collected data were tabulated and analyzed using the statistical software IBM SPSS Statistics, version 20 (IBM Inc., Chicago, Illinois, USA). The $\chi^{2}$ test were used to evaluate associations between the serological results for $N$. caninum. $P$ values $\leq 0.05$ were considered statistically significant. When the value of the expected frequencies was smaller than five Fisher's exact test was performed.

\section{Results}

The analyzed samples came from 46 of the 79 municipalities (Figure 1) in the state of Mato Grosso do Sul. In group I, the pregnant women from whom the samples were obtained had a mean age of $23.18 \pm 6.3057$ years, 


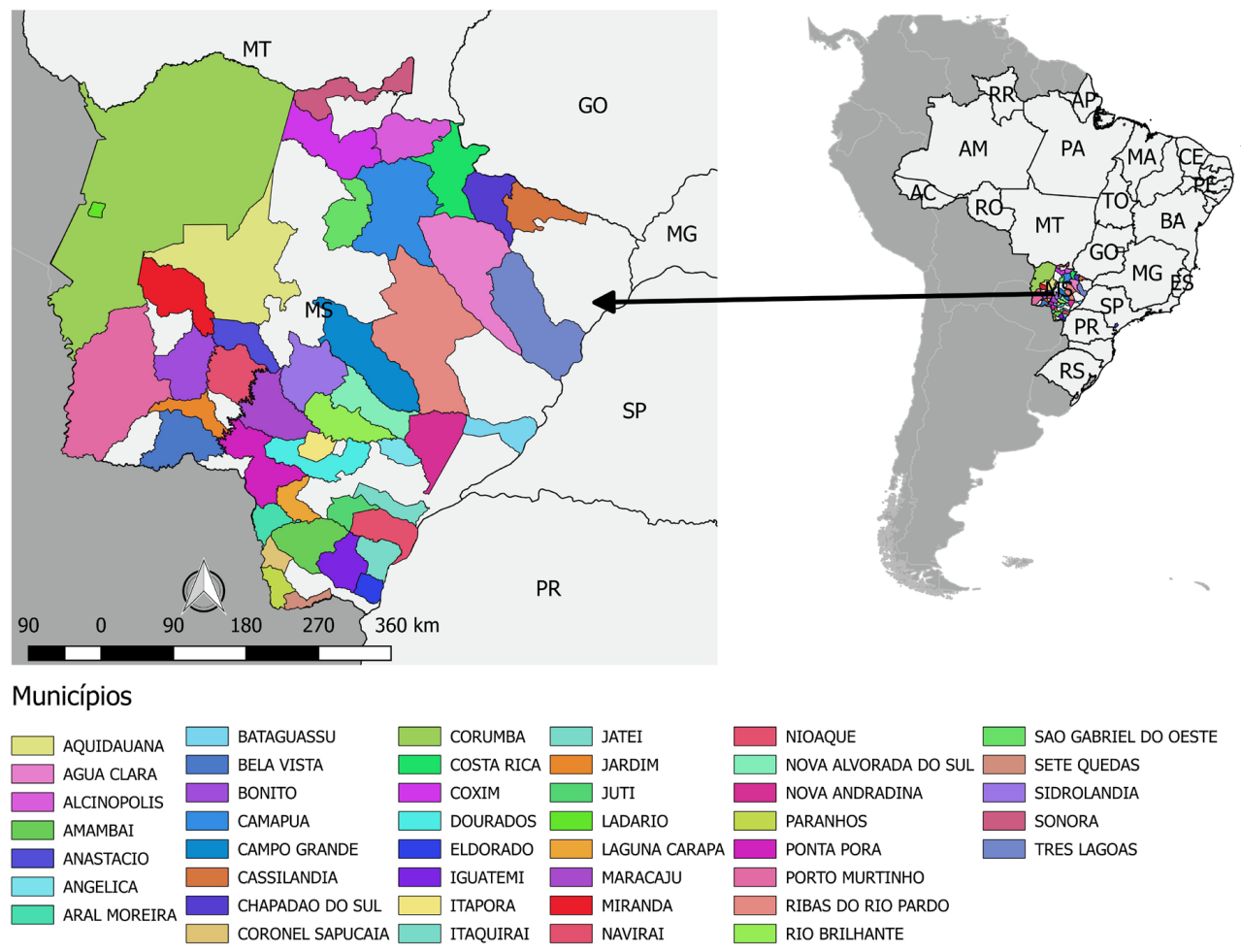

Figure 1. Map of the state of Mato Grosso do Sul, Brazil, indicating the municipalities of origin of the analyzed samples.

and according to the prenatal screening reports, $6 \%$ (6/99) of the women were positive for syphilis and $1 \%(1 / 99)$ for hepatitis B. In group II, the mean age was 23.21 years \pm 6.1173 , and 9.09\% (3/33) were positive for syphilis. In group III, the mean age was 26.58 years \pm 6.7548 years, and $14.2 \%(8 / 56)$ were positive for syphilis.

There was a significant association between age and $N$. caninum-positive cases in group III (Table 1). In group I, 30 samples were from the state capital of Campo Grande, with 11 positive for N. caninum (IgG and/or IgM), and the remaining 69 samples were from other cities in the interior of the state, 19 (with two samples positive for both antibodies) of which were positive for $N$. caninum (IgG and/or IgM). In group II, 17 samples were from the capital Campo Grande, of which 3 were positive for $N$. caninum (IgG), and the other 16 samples were from the other cities in the interior, 4 of which were positive for $N$. caninum (IgG). In group III, 21 samples were obtained from the capital Campo Grande, 7 of which were positive for $N$. caninum (IgG), and the remaining 35 samples were from other cities in the interior, 8 of which were positive for $N$. caninum (IgG and/or IgM) (Table 2).

Table 1. Seropositivity for Neospora caninum according to age group, considering the number of pregnant women positive for IgG and IgM antibodies in Mato Grosso do Sul, Brazil.

\begin{tabular}{|c|c|c|c|c|}
\hline & \multicolumn{3}{|c|}{ Neospora caninum-positive IgG/IgM } & \multirow{3}{*}{$p$ value } \\
\hline & \multicolumn{3}{|c|}{ Age } & \\
\hline & $\leq 20$ & $21-30$ & $\geq 31$ & \\
\hline \multirow[t]{2}{*}{ Group I } & $14 / 42(33.3 \%) /$ & $9 / 40(22.5 \%) /$ & $7 / 17(41.17 \%) /$ & $0.335 /$ \\
\hline & $6 / 42(14.28 \%)$ & $2 / 40(5 \%)$ & $1 / 17(5.88 \%)$ & 0.345 \\
\hline \multirow[t]{2}{*}{ Group II } & $3 / 15(20 \%) /$ & $4 / 15(26.6 \%) /$ & $0 / 3(0 \%) /$ & $1.0 /$ \\
\hline & $0 / 15(0 \%)$ & $0 / 15(0 \%)$ & $0 / 3(0 \%)$ & - \\
\hline \multirow[t]{2}{*}{ Group III } & $2 / 10(20 \%) /$ & $3 / 29(10.3 \%) /$ & $10 / 17(58.8 \%) /$ & $0.002 * 1$ \\
\hline & $0 / 10(0 \%)$ & $0 / 29(0 \%)$ & $2 / 17(11.76 \%)$ & 0.118 \\
\hline
\end{tabular}

*Indicates that $p<0.05$ is statistically significant when compared between age groups. 


\section{IFA test}

Of the 99 analyzed samples from group I, 23 (23.2\%) were positive for IgG antibodies, and 9 (9.09\%) were positive for anti-N. caninum IgM antibodies as determined by IFA test. In group II, of the 33 analyzed samples, 7 (21.2\%) were positive for IgG only. In group III, of the 56 analyzed samples, 13 (23.2\%) were positive for IgG antibodies, and 2 (3.5\%) were positive for anti-N. caninum IgM antibodies (Tables 2 and 3). According to the Fisher's exact test for the presence of IgG and IgM antibodies, the group II $(p=0.05)$, and III $(p=0.02)$ showed a difference in the proportion of positive and negative results at $p \leq 0.05$.

Table 2. Seropositivity for Neospora caninum according to the proportion of positive and negative pregnant women for IgG and IgM antibodies in each group and the Geographic distribution in Mato Grosso do Sul, Brazil.

\begin{tabular}{|c|c|c|c|}
\hline & \multicolumn{2}{|c|}{ Neospora caninum } & \multirow{3}{*}{ p value } \\
\hline & \multicolumn{2}{|c|}{ Serology } & \\
\hline & IgG & IgM & \\
\hline Group I & $23 / 99(23.2 \%)$ & $9 / 99(9.09 \%)$ & 0.07 \\
\hline Group II & $7 / 33(21.2 \%)$ & $0 / 33(0 \%)$ & $0.05^{*}$ \\
\hline \multirow[t]{3}{*}{ Group III } & $13 / 56(23.2 \%)$ & $2 / 56(3.5 \%)$ & $0.02 *$ \\
\hline & \multicolumn{2}{|c|}{ Geographic distribution of positive samples for Neospora caninum } & \multirow[b]{2}{*}{ Total } \\
\hline & $\begin{array}{c}\text { Capital } \\
\text { (Campo Grande) }\end{array}$ & Cities in the interior & \\
\hline Group I & $11 / 30(36.6 \%)$ & $19 / 69(27.5 \%)$ & 99 \\
\hline Group II & $3 / 17(17.6 \%)$ & $4 / 16(25 \%)$ & 33 \\
\hline Group III & $7 / 21(33.3 \%)$ & $8 / 35$ (22.8\%) & 56 \\
\hline
\end{tabular}

*Indicates that $\mathrm{p} \leq 0.05$ is statistically significant when compared between negative and positives antibodies.

Table 3. IFA test and western blot for anti-Neospora caninum IgG antibodies in Mato Grosso do Sul, Brazil.

\begin{tabular}{|c|c|c|c|c|c|}
\hline \multicolumn{6}{|c|}{ Neospora caninum } \\
\hline & \multirow{2}{*}{ Number of samples } & $\begin{array}{l}\text { IFA } \\
(1: 50)\end{array}$ & $\begin{array}{c}\text { IFA } \\
(1: 100)\end{array}$ & $\begin{array}{c}\text { IFA } \\
(1: 200)\end{array}$ & $\begin{array}{l}\text { Western } \\
\text { blot }\end{array}$ \\
\hline & & $+/ \%$ & $+/ \%$ & $+/ \%$ & $+/ \%$ \\
\hline Group I & 99 & $23 / 23.2$ & $7 / 7.0$ & $5 / 5.0$ & $19(82.6)$ \\
\hline Group II & 33 & $7 / 21.2$ & 0 & 0 & $6(85.7)$ \\
\hline Group III & 56 & $13 / 23.2$ & $1 / 1.7$ & 0 & $12(92.3)$ \\
\hline
\end{tabular}

\section{Western blot analysis}

The seropositivity for $N$. caninum Ig G was confirmed by western blot (Table 3 ) analysis by testing all sera positive according the IFA test. The tested sera showed reactivity with a 29-kDa protein. Group I showed $82.6 \%$ IgG positivity (19/23); group II showed $85.7 \%$ IgG positivity (6/7); and group III showed 92.3\% IgG positivity (12/13).

\section{Discussion}

In the present study, positivity for $N$. caninum was demonstrated by the IFA test and western blot analysis, which strengthens these findings because the methods are different but complementary serological techniques (Tranas et al., 1999).

For the IFA test, only $23.2 \%$ of the samples from group I were positive, indicating the low probability of crossreactivity with $T$. gondii, whereas $76.8 \%$ were negative for $N$. caninum. In group III, of the 56 samples positive for 
anti-T. gondii IgG antibodies, $76.7 \%$ were negative for $N$. caninum. These findings corroborate the literature reporting minimal or no cross-reactivity, when dilutions equal to or greater than 1:50 are used in the IFA test (Lobato et al., 2006; Tranas et al., 1999).

In groups II and III, $21.2 \%$ and $23.2 \%$ of the samples, respectively, were positive for $N$. caninum IgG antibodies. N. caninum can behave as an opportunistic pathogen in immunocompromised patients (Oshiro et al., 2015; Lobato et al., 2006), and some studies have reported similar rates in HIV-positive patients. In a study by Oshiro et al. (2015) $26.1 \%$ of samples from Mato Grosso do Sul and 31.2\% for samples from the state of Paraná were positive, whereas in the state of Minas Gerais, Lobato et al. (2006) found that 38\% of samples from HIV-positive patients and $6 \%$ of samples from healthy individuals were positive, demonstrating that the positivity rate is lower in healthy individuals. The positivity rates may vary according to the technique used and the sample size.

Positivity for anti-N. caninum IgM was observed via IFA test, with 9 samples positive in group I and 2 samples positive in group III. In the literature, there are no data on anti-N. caninum IgM in humans, and the role of the humoral immune response has not yet been elucidated in individuals exposed to the parasite. However, the presence of specific IgM antibodies is indicative of recent infection. A study conducted in the laboratory with mice showed the production of $N$. caninum-specific IgM on the seventh day after challenge, followed by IgG production starting on the fourteenth day (Teixeira et al., 2005).

There was a significant association between age and $\mathrm{N}$. caninum positive cases in group III, but there are no data in the literature relating positivity to age in humans. However, according to Dubey et al. (2012), one of the main risk factors for $T$. gondii infection in Brazil is advanced age, as there is increased exposure to the parasite. The significant association between positivity for N. caninum and the proportion of pregnant women positive and negative for only lgG in each group is indicative of past infection.

Reactivity to the N. caninum surface antigen rNcSRS2 (Nc-p43) via western blot, 82.6\% (19/23) for group I, $85.7 \%$ (6/7) for group II and $92.3 \%$ (12/13) for group III, demonstrates that these samples are truly positive because rNcSRS2 (Nc-p43) is highly immunogenic and well-conserved (Howe et al., 1998).

Oshiro et al. (2016) used this same protein to develop an indirect serological test (ELISA) to detect anti-N. caninum antibodies in humans and showed sensitivity of $100 \%$ and specificity of $90 \%$. In a study carried out by Nam et al. (1998) with human samples of negative and positive sera for T. gondii, the reactivity for a 43 KDa surface protein was observed in the western blot for $N$. caninum. Three samples showed reactivity, two from the positive group for $T$. gondii and one from the negative group. This protein seems to be the same used in the present study, however it is not clear in what conditions the western blot was performed and we must take into account that in the present study the recombinant partial sequence of the respective protein was used.

According to Howe \& Sibley (1999), the NcSRS2 protein (Nc-p43) has 35 KDa in non-denaturing conditions (without $\beta$-mercaptoethanol) and proteins with similar molecular weight have been reported by Lobato et al. (2006) and Tranas et al. (1999) in human sera. Each host species is able to develop its own standard for anti-N. caninum antibodies and variations in the techniques used for the gel, electrophoresis, sample preparation, antigen sources and antibody detection can interfere with the molecular weight variation (Lobato et al., 2006). Studies conducted by Hemphill et al. (1997) and Howe et al. (1998) revealed that the partial nucleotide sequence of the gene encoding NcSRS2 (Nc-p43) has sequence homology with the SRS2 gene from T. gondii, but it was determined by immunotransfer that cross reactivity with $T$. gondii appears to be insignificant (Bjerkas et al., 1994; Paré et al., 1998; Bae et al., 2000).

Regional conditions must be taken into account so that there is a better understanding of the interaction between antigen and antibody for N. caninum (Lima et al., 2007). Although the rNcSRS2 protein (Nc-p43) did not cross-react with T. gondii in the serum of cattle, dogs and sheep (Borsuk et al., 2011; Pinheiro et al., 2015), further studies are needed to assess the interaction of this antigen with antibodies, from human samples positive for T. gondii.

Neospora caninum is transmitted very efficiently by the transplacental route in cattle (Dubey, 2003), and neosporosis is an important cause of abortion in these animals (Barros et al., 2011). According to data from the Brazilian Institute of Geography and Statistics (IBGE, 2018), Mato Grosso do Sul has the fourth largest cattle herd in Brazil. The seroprevalence for N. caninum in cattle in the state ranged from 14.9\% to 43\% (Ragozo et al., 2003; Andreotti et al., 2004; Oshiro et al., 2007). A study by Benetti et al. (2009) found a seroprevalence of $N$. caninum of $10.5 \%$ in rural workers and $53.5 \%$ in cattle in the state of Mato Grosso. The possibility that N. caninum can infect humans should not be ruled out, as serological evidence in humans is well described in the literature, suggesting exposure to the parasite (Oshiro et al., 2015; Ibrahim et al., 2009; Lobato et al., 2006; Tranas et al., 1999). 
An in vitro study showed N. caninum is able to infect human cervical cells and trophoblasts (Carvalho et al., 2010). In experimental studies conducted with nonhuman primates, infection by $N$. caninum was similar to that induced by $T$. gondii, indicating susceptibility to transplacental infection and fetal lesions (Ho et al., 1997; Barr et al., 1994).

Although viable $N$. caninum parasites have not yet been reported in human tissues, DNA was detected for the first time in two umbilical cord blood samples in a study conducted by Duarte et al. (2020) in Brazil. In Spain, among 600 human samples analyzed, none showed positivity for $N$. caninum (Calero-Bernal et al., 2019). It is not clear whether $N$. caninum is capable of causing a disease similar to infection by $T$. gondii and further studies are needed to clarify this possibility.

The serological results of the present study suggest that exposure of these pregnant women to the $N$. caninum parasite and the presence of IgM antibodies are indicative of recent infection. The role of $N$. caninum in human pregnancies is not yet clear, but it is known that in mammals such as cattle, sheep and goats, can cause abortion and fetal resorption and mummification; thus, we cannot rule out the possibility that $N$. caninum is potentially harmful to human pregnancies. Further studies are needed to establish the possibility of active infection.

\section{Acknowledgements}

This study was financed in part by the Coordenação de Aperfeiçoamento de Pessoal de Nível Superior - Brasil (CAPES) Finance Code 001. This study was financed in part by the Fundação Universidade Federal de Mato Grosso do Sul - UFMS/MEC - Brazil. We thank IPED/ APAE for their collaboration.

\section{References}

Andreotti R, Pinckney RD, Pires PP, Silva EA. Evidence of Neospora caninum in beef cattle and dogs in the state of Mato Grosso do Sul, center-western region, Brazil. Rev Bras Parasitol Vet 2004; 13(3): 129-131.

Bae JS, Kim DY, Hwang WS, Kim JH, Lee NS, Nam HW. Detection of IgG antibody against Neospora caninum in cattle in Korea. Korean J Parasitol 2000; 38(4): 245-249. http://dx.doi.org/10.3347/kjp.2000.38.4.245. PMid:11138317.

Barr BC, Conrad PA, Sverlow KW, Tarantal AF, Hendrickx AG. Experimental fetal and transplacental Neospora infection in the nonhuman primate. Lab Invest 1994; 71(2): 236-242. PMid:8078303.

Barratt JLN, Harkness J, Marriott D, Ellis JT, Stark D. Importance of nonenteric protozoan infections in immunocompromised people. Clin Microbiol Rev 2010; 23(4): 795-836. http://dx.doi.org/10.1128/CMR.00001-10. PMid:20930074.

Barros JC, Figueiredo LF No, Fagundes MBB, Andreotti R. Economic assesment of neosporosis in beef cattle system performance with different technological levels. Semina: Ciênc Agrár 2011;32(4 Suppl 1): 1943-1954. http://dx.doi.org/10.5433/16790359.2011v32n4Sup1p1943.

Benetti AH, Schein FB, dos Santos TR, Toniollo GH, da Costa AJ, Mineo JR, et al. Pesquisa de anticorpos anti-Neospora caninum em bovinos leiteiros, cães e trabalhadores rurais da região Sudoeste do Estado de Mato Grosso. Rev Bras Parasitol Vet 2009;18(Suppl 1): 29-33. http://dx.doi.org/10.4322/rbpv.018e1005. PMid:20040187.

Bjerkas I, Jenkins MC, Dubey JP. Identification and characterization of Neospora caninum tachyzoite antigens useful for diagnosis of neosporosis. Clin Diagn Lab Immunol 1994; 1(2): 214-221. http://dx.doi.org/10.1128/CDLI.1.2.214-221.1994. PMid:7496948.

Borsuk S, Andreotti R, Leite FP, Pinto LS, Simionatto S, Hartleben CP, et al. Development of an indirect ELISA-NcSRS2 for detection of Neospora caninum antibodies in cattle. Vet Parasitol 2011; 177(1-2): 33-38. http://dx.doi.org/10.1016/j.vetpar.2010.11.026. PMid:21168278.

Calero-Bernal R, Horcajo P, Hernández M, Ortega-Mora LM, Fuentes I. Absence of Neospora caninum DNA in Human Clinical Samples, Spain. Emerg Infect Dis 2019; 25(6): 1226-1227. http://dx.doi.org/10.3201/eid2506.181431. PMid:31107232.

Carvalho JV, Alves CM, Cardoso MR, Mota CM, Barbosa BF, Ferro EA, et al. Differential susceptibility of human trophoblastic (BeWo) and uterine cervical (HeLa) cells to Neospora caninum infection. Int J Parasitol 2010; 40(14): 1629-1637. http://dx.doi. org/10.1016/j.ijpara.2010.06.010. PMid:20708622.

Duarte PO, Oshiro LM, Zimmermann NP, Csordas BG, Dourado DM, Barros JC, et al. Serological and molecular detection of Neospora caninum and Toxoplasma gondii in human umbilical cord blood and placental tissue samples. Sci Rep 2020; 10(1): 9043. http://dx.doi.org/10.1038/s41598-020-65991-1. PMid:32493968.

Dubey JP, Carpenter JL, Speer CA, Topper MJ, Uggla A. Newly recognized fatal protozoan disease of dogs. J Am Vet Med Assoc 1988; 192(9): 1269-1285. PMid:3391851. 
Dubey JP, Jenkins MC, Rajendran C, Miska K, Ferreira LR, Martins J, et al. Gray wolf (Canis lupus) is a natural definitive host for Neospora caninum. Vet Parasitol 2011; 181(2-4): 382-387. http://dx.doi.org/10.1016/j.vetpar.2011.05.018. PMid:21640485.

Dubey JP, Lago EG, Gennari SM, Su C, Jones JL. Toxoplasmosis in humans and animals in Brazil: high prevalence, high burden of disease, and epidemiology. Parasitology 2012; 139(11): 1375-1424. http://dx.doi.org/10.1017/S0031182012000765. PMid:22776427.

Dubey JP, Schares G, Ortega-Mora LM. Epidemiology and control of neosporosis and Neospora caninum. Clin Microbiol Rev 2007; 20(2): 323-367. http://dx.doi.org/10.1128/CMR.00031-06. PMid:17428888.

Dubey JP. Review of Neospora caninum and neosporosis in animals. Korean J Parasito/ 2003; 41(1): 1-16. http://dx.doi.org/10.3347/ kjp.2003.41.1.1. PMid:12666725.

Gondim LFP, McAllister MM, Pitt WC, Zemlicka DE. Coyotes (Canis latrans) are definitive hosts of Neospora caninum. Int J Parasitol 2004; 34(2): 159-161. http://dx.doi.org/10.1016/j.ijpara.2004.01.001. PMid:15037103.

Hemphill A, Felleisen R, Connolly B, Gottstein B, Hentrich B, Müller N. Characterization of a cDNA-clone encoding Nc-p43, a major Neospora caninum tachyzoite surface protein. Parasitology 1997; 115(Pt 6): 581-590. http://dx.doi.org/10.1017/S0031182097001650. PMid:9488869.

Hemphill A, Fuchs N, Sonda S, Hehl A. The antigenic composition of Neospora caninum. Int J Parasitol 1999; 29(8): $1175-1188$. http://dx.doi.org/10.1016/S0020-7519(99)00085-5. PMid:10576569.

Ho MS, Barr BC, Tarantal AF, Lai LT, Hendrickx AG, Marsh AE, et al. Detection of Neospora from tissues of experimentally infected rhesus macaques by PCR and specific DNA probe hybridization.J Clin Microbio/ 1997; 35(7): 1740-1745. http://dx.doi.org/10.1128/ JCM.35.7.1740-1745.1997. PMid:9196184.

Howe DK, Crawford AC, Lindsay D, Sibley LD. The p29 and p35 immunodominant antigens of Neospora caninum tachyzoites are homologous to the family of surface antigens of Toxoplasma gondii. Infect Immun 1998; 66(11): 5322-5328. http://dx.doi. org/10.1128/IAI.66.11.5322-5328.1998. PMid:9784539.

Howe DK, Sibley LD. Comparison of the major antigens of Neospora caninum and Toxoplasma gondii. Int J Parasitol 1999; 29(10): 1489-1496. http://dx.doi.org/10.1016/S0020-7519(99)00099-5. PMid:10608434.

Ibrahim HM, Salem TA, Huang P, Nishikawa Y, Xuan X, Nasr MI, et al. Prevalence of Neospora caninum and Toxoplasma gondii antibodies in northern Egypt. Am J Trop Med Hyg 2009; 80(2): 263-267. http://dx.doi.org/10.4269/ajtmh.2009.80.263. PMid:19190225.

Instituto Brasileiro de Geografia e Estatística - IBGE. Efetivo do rebanho [online]. Rio de Janeiro: IBGE; 2018 [cited 2020 Feb 10]. Available from: https://cidades.ibge.gov.br/brasil/ms/pesquisa/18/16459?tipo=ranking\&indicador=16533

King JS, Slapeta J, Jenkins DJ, Al-Qassab SE, Ellis JT, Windsor PA. Australian dingoes are definitive hosts of Neospora caninum. Int J Parasitol 2010; 40(8): 945-950. http://dx.doi.org/10.1016/j.ijpara.2010.01.008. PMid:20149793.

Lima MSC Jr, Andreotti R, Caetano AR, Paiva F, Matos MFC. Cloning and expression of an antigenic domain of a major surface protein (Nc-p43) of Neospora caninum. Rev Bras Parasitol Vet 2007; 16(2): 61-66. PMid:17706005.

Lobato J, Silva DAO, Mineo TWP, Amaral JDHF, Segundo GRS, Costa-Cruz JM, et al. Detection of immunoglobulin G antibodies to Neospora caninum in humans: high seropositivity rates in patients who are infected by human immunodeficiency virus or have neurological disorders. Clin Vaccine Immuno/ 2006; 13(1): 84-89. http://dx.doi.org/10.1128/CVI.13.1.84-89.2006. PMid:16426004.

McAllister MM, DubeyJP, Lindsay DS, Jolley WR, Wills RA, McGuire AM. Dogs are definitive hosts of Neospora caninum. Int J Parasitol 1998; 28(9): 1473-1478. PMid:9770635.

Nam HW, Kang SW, Choi WY. Antibody reaction of human anti-Toxoplasma gondii positive and negative sera with Neospora caninum antigens. Korean J Parasitol 1998; 36(4): 269-275. http://dx.doi.org/10.3347/kjp.1998.36.4.269. PMid:9868893.

Oshiro LM, Cunha RC, Duarte PO, Santos AG Jr, Sanches CC, Leite FPL, et al. The development of an indirect ELISA test using the recombinant protein NcSRS2 to detect anti-Neospora caninum antibodies in humans. Jacobs J Vet Sci Res 2016; 3(3): 1-5.

Oshiro LM, Matos MF, de Oliveira JM, Monteiro LA, Andreotti R. Prevalence of anti-Neospora caninum antibodies in cattle from the state of Mato Grosso do Sul, Brazil. Rev Bras Parasitol Vet 2007; 16(3): 133-138. http://dx.doi.org/10.1590/S198429612007000300004. PMid:18078599.

Oshiro LM, Motta-Castro ARC, Freitas SZ, Cunha RC, Dittrich RL, Meirelles ACF, et al. Neospora caninum and Toxoplasma gondii serodiagnosis in human immunodeficiency virus carriers. Rev Soc Bras Med Trop 2015; 48(5): 568-572. http://dx.doi. org/10.1590/0037-8682-0151-2015. PMid:26516966.

Paré J, Fecteau G, Fortin M, Marsolais G. Seroepidemiologic study of Neospora caninum in dairy herds. J Am Vet Med Assoc 1998; 213(11): 1595-1598. PMid:9838960.

Paré J, Hietala SK, Thurmond MC. Interpretation of an indirect fluorescent antibody test for diagnosis of Neospora sp. infection in cattle. J Vet Diagn Invest 1995; 7(2): 273-275. http://dx.doi.org/10.1177/104063879500700222. PMid:7619917. 
Pinheiro AF, Borsuk S, Berne MEA, Pinto LS, Andreotti R, Roos T, et al. Use of ELISA based on NcSRS2 of Neospora caninum expressed in Pichia pastoris for diagnosing neosporosis in sheep and dogs. Rev Bras Parasitol Vet 2015; 24(2): 148-154. http:// dx.doi.org/10.1590/S1984-29612015015. PMid:26083692.

Ragozo AMA, Paula VSO, Souza SLP, Bergamaschi DP, Gennari SM. Ocorrência de anticorpos anti-Neospora caninum em soros bovinos procedentes de seis estados brasileiros. Rev Bras Parasitol Vet 2003; 12(1): 33-37.

Teixeira L, Marques A, Meireles CS, Seabra AR, Rodrigues D, Madureira P, et al. Characterization of the B-cell immune response elicited in BALB/c mice challenged with Neospora caninum tachyzoites. Immunology 2005; 116(1): 38-52. http://dx.doi.org/10.1111/ j.1365-2567.2005.02195.x. PMid:16108816.

Tranas J, Heinzen RA, Weiss LM, McAllister MM. Serological evidence of human infection with the protozoan Neospora caninum. Clin Diagn Lab Immunol 1999; 6(5): 765-767. http://dx.doi.org/10.1128/CDLI.6.5.765-767.1999. PMid:10473533. 